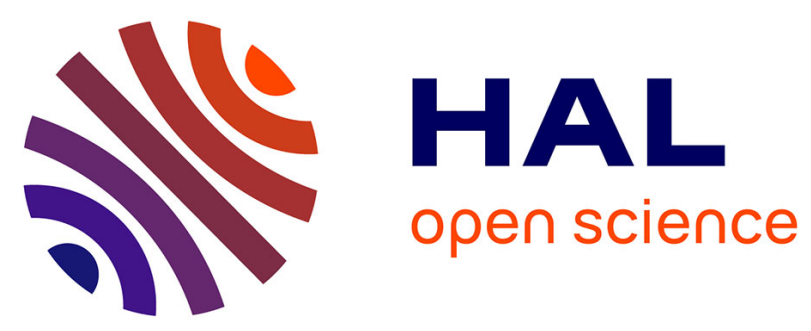

\title{
Regulating insect resistance management: the case of non-Bt corn refuges in the US
}

\author{
Denis D. Bourguet, Marion Desquilbet, Stephane Lemarié
}

\section{To cite this version:}

Denis D. Bourguet, Marion Desquilbet, Stephane Lemarié. Regulating insect resistance management: the case of non-Bt corn refuges in the US. Journal of Environmental Management, 2005, 76 (3), pp.210-220. 10.1016/j.jenvman.2005.01.019 . hal-02682661

\section{HAL Id: hal-02682661 \\ https://hal.inrae.fr/hal-02682661}

Submitted on 12 Aug 2020

HAL is a multi-disciplinary open access archive for the deposit and dissemination of scientific research documents, whether they are published or not. The documents may come from teaching and research institutions in France or abroad, or from public or private research centers.
L'archive ouverte pluridisciplinaire HAL, est destinée au dépôt et à la diffusion de documents scientifiques de niveau recherche, publiés ou non, émanant des établissements d'enseignement et de recherche français ou étrangers, des laboratoires publics ou privés.

\section{(1) (1) $\$$}

Distributed under a Creative Commons Attribution - NonCommercial - NoDerivatives| 4.0 


\title{
Regulating insect resistance management: the case of non- $B t$ corn refuges in the US
}

\author{
Denis Bourguet $^{\mathrm{a}}$, Marion Desquilbet ${ }^{\mathrm{b}, *}$, Stéphane Lemarié ${ }^{\mathrm{b}}$ \\ ${ }^{\mathrm{a}}$ Centre de Biologie et de Gestion des Populations (CBGP), UMR INRA/IRD/CIRAD/ENSA.M, Campus International de Baillarguet, \\ CS 30 016, 34988 Montferrier/Lez, France \\ ${ }^{\mathrm{b}}$ GAEL, Institut National de la Recherche Agronomique-Université Pierre Mendes France, BP 47, 38040 Grenoble cedex 9, France
}

\begin{abstract}
In this paper, we analyze the insect resistance management (IRM) plan put in place by the US Environmental Protection Agency (EPA) to delay the evolution of resistance to $B t$ corn in natural populations of the European corn borer, Ostrinia nubilalis Hübner. This IRM plan is the most impressive mandatory IRM system ever developed. It forms a coherent whole and includes mandatory refuges, actions to increase growers' compliance and a program for monitoring the evolution of resistance. However, our analysis suggests that two components of this IRM plan are not entirely satisfactory: growers' compliance and monitoring of the evolution of resistance. Moreover, the implementation of these two components of IRM has been required of the registrants, whose incentives for IRM are probably lower than the social optimum. Our analysis suggests that alternatives to the IRM plan currently in place could improve these two components.
\end{abstract}

(C) 2005 Elsevier Ltd. All rights reserved.

Keywords: Environmental policy; Natural resources; Insect resistance management; High-dose structured refuge strategy

\section{Introduction}

The insecticides and pest-resistant transgenic varieties used to prevent crop damage exert a selection pressure on insect pest populations. Over time, the efficacy of these pest control products may decrease if the incidence of pest resistance increases. Numerous cases of pest resistance to insecticides have already been identified (Taylor and Feyereisen, 1996). Scientists and practitioners have responded by developing various insect resistance management (IRM) strategies, aimed at delaying the buildup of insecticide resistance in pest populations and managing established resistant pest populations (NRC, 1986; Green et al., 1990). These strategies may be implemented either at farm level (changes in cultural practices, alternation of chemical insecticides, refuges) or at input level (insecticide

\footnotetext{
* Corresponding author. Tel.: +33 4768256 88; fax: +33 47682 5455.

E-mail addresses: bourguet@ensam.inra.fr (D. Bourguet), desquilb@ grenoble.inra.fr (M. Desquilbet), lemarie@grenoble.inra.fr (S. Lemarié).
}

mixtures, seed mixes or gene stacking for pest-resistant transgenic varieties) (see Roush, 1998 for a review). In economic terms, the stock of pest susceptibility to a given pest control product is a beneficial non-renewable resource (Hueth and Regev, 1974), and IRM strategies slow down the depletion of this stock. ${ }^{1}$ The economic objective of IRM is therefore the optimal extraction of this susceptibility resource over time.

Despite the potential benefits associated with delaying the evolution of insecticide resistance, several difficulties may hamper the effective implementation of IRM strategies. First, if the insect pests concerned are mobile, their susceptibility is a common property resource for all farmers in the area. The level of implementation of IRM strategies at farm level may, therefore, be low without appropriate IRM regulation, because crop protection by an individual farmer decreases the stock of susceptibility available to other farmers. However, individual farmers tend to disregard this effect and overuse the susceptibility resource, applying large amounts of pesticides (Regev et al., 1983). Second,

\footnotetext{
${ }^{1}$ Actually susceptibility may be a renewable resource if there is a fitness cost of resistance (i.e. if resistant individuals have a lower fitness than susceptible individuals).
} 
the attractiveness of IRM for suppliers of pest control products depends on market structure (Miranowski and Carlson in NRC, 1986). It will be difficult to implement IRM strategies at the input level if pest susceptibility is a common property resource for competitors selling analogous pest control products, or if such strategies require mixtures or the stacking of products produced by competitors. Third, the effectiveness of an IRM plan depends on several characteristics of pest populations: pest population dynamics, evolution of resistance, crop damage caused by pests, and their interaction with pest control products and pest management strategies. In most cases, these characteristics are known only imperfectly and, in addition, some are stochastic. Inadequate information concerning these characteristics may reduce the success of IRM, but it may be expensive to obtain the extra information required.

We aim here to analyze how these difficulties were overcome in the special case of IRM for $B t$ corn resistant to the European corn borer (ECB), Ostrinia nubilalis Hübner (Lepidoptera: Crambidae) in the United States (US). ${ }^{2} B t$ crops are transgenic crops that produce the toxins of the bacterium Bacillus thuringiensis $(B t)$. Bt toxins make these crops resistant to some target insects. Mandatory refuge requirements came into effect in 1995 for $B t$ cotton and in 2000 for $B t$ field corn and potato. IRM regulations require that each registrant require each farmer growing an insectresistant $B t$ crop to grow a conventional non insect-resistant variety on some part of his or her acreage, in close proximity to $B t$ fields. Areas planted with non- $B t$ varieties are called refuges. These refuges are designed to maintain a pool of susceptible insects to delay the buildup of resistance to $B t$ crops in target insects. IRM regulations also include requirements to collect and/or improve knowledge related to resistance management, to monitor the evolution of resistance in insect populations, and to assess and enhance farmer compliance with refuge requirements.

This case study provided us with an opportunity to identify practical difficulties associated with IRM, because this is the first large-scale mandatory IRM plan to be implemented; all previous IRM plans have been voluntary (Green et al., 1990). Therefore, with this IRM plan, policymakers have had to tackle the issues of incentives for farmers and input suppliers and of the cost of information gains more directly than in any previous IRM program. Our case study is also interesting in its multidisciplinary approach, covering both biological and economic aspects of the IRM plan, and making it possible to study the interaction of these two aspects.

In Section 2, we explain why this IRM plan was made mandatory and describe its regulation. In Section 3, we present the IRM strategy retained, the studies undertaken to

\footnotetext{
${ }^{2}$ Bt corn resistant to the Western corn rootworm, Diabrotica virgifera virgifera Le conte, has been registered in the US in 2003. The IRM for this $B t$ corn is beyond the scope of this paper.
}

gain sufficient information about relevant biological characteristics, and the definition of the biological components. In Section 4, we discuss issues relating to farmer compliance: the costs of compliance, compliance enhancement and compliance measurement. In Section 5, we describe the methods selected for monitoring the evolution of insect resistance. We then present our conclusions in Section 6.

\section{The regulatory framework for IRM for $B t$ crops}

\subsection{The scope of the EPA to intervene in IRM for Bt crops}

The US Environmental Protection Agency (EPA) has authority over IRM for $B t$ crops by virtue of its regulatory jurisdiction over pesticides under the Federal Insecticide, Fungicide, and Rodenticide Act (FIFRA). This law requires the EPA to register all pesticides used in the US and to assure that they do not cause unreasonable harm to human health and the environment if used in accordance with EPAapproved specifications. To prevent unreasonable adverse effects, the EPA may impose conditions and restrictions on pesticide use. The FIFRA also applies to so-called plantincorporated protectants (PIPs) — pesticidal substances that plants produce from genetic material incorporated into their genomes (including $\mathrm{Bt}$ pesticidal proteins produced in $\mathrm{Bt}$ crops and their genetic material) (Federal Register, 2001). The EPA has registered transgenic Bt PIPs expressed in transgenic potato, corn and cotton (Table 1). For all Bt products, the registrations currently in effect include the laying down of IRM requirements.

\subsection{Justification of IRM regulation for Bt crops}

IRM regulation for $B t$ crops has been subject to considerable debate. Three arguments have been put forward to justify such regulation (Mellon and Rissler, 1998; EPA, 1998; NRC, 2000). First, $B t$ toxins are the active component in microbial $B t$ sprays used by organic farmers for pest control. Environmentalists and organic farming groups were concerned that this means of control would be lost if the widespread commercial planting of $B t$ crops led to the rapid development of insect resistance to $B t$ toxins. Second, EPA claimed that $B t$ crops may reduce human and environmental exposure to pesticides. Insect resistance to $B t$ crops would push farmers to use chemical insecticides as replacement products, an alternative considered less benign by the EPA (see the detailed analysis in Glaser and Matten, 2003). Third, there have been concerns that resistance buildup was likely to be more rapid for $B t$ crops than for conventional insecticides (Gould, 1998; EPA, 1998). Indeed, the $B t$ toxins in $B t$ crops exert strong selection pressure for resistance (mortality levels are often $>99 \%$ ) throughout the season, whereas conventional insecticides exert a weaker selection pressure (mortality level may be 
Table 1

Detailed list of transgenic Bt crops

\begin{tabular}{|c|c|c|c|c|c|}
\hline Crop & Name of the GMO PIP & Trademark & Name of the $B t$ toxin & Registrant & Registration process \\
\hline Potato & & $\begin{array}{l}\text { NewLeaf }{ }^{\circledR} \\
\text { NewLeafPlus }{ }^{\circledR}\end{array}$ & Cry3Ab & Monsanto & $\begin{array}{l}\text { May } 1995 \text { (NewLeaf), and Dec } 1998 \\
\text { (NewLeafPlus), no time-limit }\end{array}$ \\
\hline \multirow[t]{2}{*}{ Cotton } & Mon 531 & Bollgard $^{\circledR}$ & Cry1Ac & Monsanto & $\begin{array}{l}\text {-Oct } 1995 \text { until } 2001 \\
\text {-Renewed in } 2001 \text { until } 2006^{\mathrm{a}}\end{array}$ \\
\hline & 15985 & Bollgard II & Cry $1 \mathrm{Ac}+\mathrm{Cry} 2 \mathrm{Ab}$ & Monsanto & -Dec. 2002 until 2004 \\
\hline \multirow[t]{8}{*}{ Corn } & 176 & $\begin{array}{l}\text { KnockOut }^{\circledR} \\
\text { NaturGard }^{\circledR}\end{array}$ & Cry $1 \mathrm{Ab}$ & Syngenta \& Dow & $\begin{array}{l}\text {-Aug } 1995 \text { until } 2001 \\
\text {-Expired in } 2001\end{array}$ \\
\hline & Bt 11 & $\begin{array}{l}\text { YieldGard }^{\circledR} \\
\text { Attribute }^{\circledR}\end{array}$ & Cry1Ab & Syngenta & $\begin{array}{l}\text {-Aug } 1996 \text { until } 2001 \\
\text {-Renewed in } 2001 \text { until } 2008\end{array}$ \\
\hline & Mon 810 & YieldGard $^{\circledR}$ & Cry1Ab & Monsanto & $\begin{array}{l}\text {-Dec } 1996 \text { until } 2001 \\
\text {-Renewed in } 2001 \text { until } 2008\end{array}$ \\
\hline & DBT418 & $B t$-Xtra ${ }^{\circledR}$ & Cry1Ac & DeKalb (Monsanto) & $\begin{array}{l}\text {-Mar } 1997 \text { until } 2001 \\
\text {-Voluntarily cancelled in } 2000\end{array}$ \\
\hline & $\mathrm{CBH}-351$ & StarLink $^{\circledR}$ & Cry9c & Aventis (Bayer) & $\begin{array}{l}\text {-May } 1998 \text { until } 2000 \\
\text {-Voluntarily cancelled in } 2001\end{array}$ \\
\hline & TC 1507 & Herculex $^{\circledR}$ & Cry1F & $\begin{array}{l}\text { Pioneer (DuPont) \& } \\
\text { Dow }\end{array}$ & Oct 2001 until 2008 \\
\hline & Mon 863 & $\begin{array}{l}\text { YieldGard } \\
\text { Rootworm }^{\circledR}\end{array}$ & Cry3Bb1 & Monsanto & Feb 2003 until 2006 \\
\hline & $\begin{array}{l}\text { (stacked) Mon } 863 \& \\
\text { Mon } 810\end{array}$ & YieldGard Plus ${ }^{\circledR}$ & Cry3Bb1 + Cry $1 \mathrm{Ab}$ & Monsanto & Oct 2003 until 2006 \\
\hline
\end{tabular}

Source: EPA, 2001, http://www.epa.gov/pesticides/biopesticides/pips/pip_list.htm and http://www.agbios.com.

a $5 \%$ external, unsprayed refuge expires in Sept 2004.

$<50 \%$ ) and are typically used only when pest populations cause substantial yield losses.

These three arguments are the basis of calls for IRM regulation for $B t$ crops, not only to correct the two negative externalities on organic farmers and on health and the environment, but also to extend the lifetime of $B t$ crops to the benefit of their users. ${ }^{3}$ The EPA made the determination that protection of Bt susceptibility was in the 'public good' and mandated IRM requirements in order to delay the development of resistance to Bt PIPs (EPA, 1998; EPA, 2001). However, the EPA has not clearly defined in formal documents the relative weights given to the views of $B t$ growers, organic farmers and to health and environmental effects in the objectives of the IRM plan. The precise goal of this strategy, in terms of the time horizon on which resistance development should be delayed or growers' profit should be maximized, has not been defined either. Moreover, it is not clear from the 'public good' argument why there should be mandatory IRM plans for $B t$ crops whereas such plans have been voluntary for other pest control products. As pointed out by the National Research Council (NRC), the EPA has not commented in formal documents on the conditions under which it regards pest resistance to be an important public or social problem (NRC, 2000).

\footnotetext{
${ }^{3}$ Regulation is needed to prevent resistance to build up too rapidly because all target pests of $B t$ crops are mobile. As a result, the susceptibility of these pests to $B t$ toxins is a common property resource for $B t$ crop growers, who do not have the right individual incentives to implement what is collectively optimal for them.
}

The mandatory IRM plans now in place result partly from the involvement of various stakeholders in the political process. Industry representatives have claimed that it is the responsibility of industry to ensure the successful development and implementation of resistance management strategies (EPA, 1998), and have therefore pushed for minimal regulation. This group was also probably concerned that any regulatory step in IRM for Bt PIPs would create a precedent and increase the likelihood that IRM would be regulated in the future, especially for transgenic crops. Conversely, environmentalists have been very active in pressuring the EPA to regulate IRM. The issue has also probably gained some credence because of the involvement of scientists.

\subsection{The process for regulating IRM}

The first $B t$ PIP registration was for a potato event in May 1995. The EPA did not impose a mandatory IRM plan for this event. Various environmentalist and organic farming groups mobilized their activists to pressure the EPA. In August 1995, when the first Bt corn PIP registration occurred, the EPA made refuges mandatory, although these refuges did not actually have to be in place at the time of registration. The first $B t$ cotton PIP registration occurred in October 1995, with an effective mandatory IRM plan from the time of registration.

Six Bt corn PIPs were registered between 1995 and 1998 (see Table 1). Initially, too little solid scientific information was available for the definition of a relevant IRM plan, 
and the EPA expected market penetration of $B t$ corn to be slow enough for non- $B t$ corn crops to act as 'unstructured' refuges while additional research was conducted (EPA, 2001). The EPA, therefore, allowed Bt corn registrants to implement voluntary IRM plans, but required these registrants to conduct additional research and to submit a refuge strategy by 1999. The period from 1995 to 2000, inclusive, was a period of knowledge accumulation and exchanges between the various stakeholders, notably for $B t$ corn, for which several IRM plans were in place. Finally, a single mandatory IRM scheme was approved and implemented in 2000 for all $B t$ field corn products aimed at controlling damages performed by ECB larvae.

\subsection{Requirements of compliance and monitoring actions by registrants}

IRM plans are mandatory for all $B t$ crops that are currently commercialized in the US. The EPA has authority over all product registrants, but for PIPs, extends this authority only to registrants who are the actual pesticide producers, but not to individual growers. The measures are therefore imposed on registrants as enforceable conditions of the pesticide registrations issued under FIFRA. If registrants fail to comply with the terms of the conditions, the EPA may rescind their registration (EPA, 1998, 2001, Howie in EPA and USDA, 1999b; Taylor and Tick, 2003). More specifically, for Bt corn, the EPA requires registrants to promote compliance with IRM plans among $B t$ growers, to monitor for the development of resistance and to apply a remedial plan in cases of established resistance (EPA, 2001). These requirements will be analyzed later in more detail, but at this stage it should simply be noted that several stakeholders questioned the decision of the EPA to restrict these measures to registrants (see notably SAP, 2001; Benbrook, 2001).

Registrants have an interest in IRM, because it increases the time window during which they are able to sell $B t$ seeds. However, three lines of argument suggest that registrants' incentives for preserving pest susceptibility are lower than the social optimum. First, registrants have no reason to take into account negative externalities of $B t$ crops on organic farmers, who use $B t$ sprays, and on health and the environment. Second, pest susceptibility to $B t$ toxins is a common property resource for registrants selling competing $B t$ seeds that produce the same toxin (e.g. Mon 810 and Bt11 for $B t$ corn, see Table 1). ${ }^{4}$ Third, registrants have no incentive to preserve pest susceptibility after they lose their patents on $B t$ seeds, whereas it may be socially optimal to

\footnotetext{
${ }^{4}$ Pest susceptibility could also be a resource common to several registrants if some competitors sold products with a high potential for cross-resistance. This was the case before 2000 when the event DBT418 was commercialized, since it produces the toxin Cry1Ac that has some common binding sites with Cry1Ab (EPA, 1998). Currently commercialized $B t$ corns against the ECB produce either Cry1 Ab or Cry1F, two toxins with different binding sites.
}

preserve susceptibility for a longer period of time, especially if no efficient alternative technique is available.

It is unclear whether the threat of rescinding registrants' permission to sell $B t$ seeds is sufficient to counterbalance these deficiencies in their incentives. The alternative would be the direct involvement of the EPA in compliance and monitoring actions. However, this would require major institutional changes, because the EPA operates under limited financial resources. Moreover, some authors (Taylor and Tick, 2003) argue that the EPA has never enforced farmers' compliance in any other program, and that historical resistance of growers to on-farm government enforcement of FIFRA rules creates a real political obstacle to the strong government enforcement of PIP use restrictions.

\section{Definition of the refuge requirement}

\subsection{The 'high-dose structured refuge' strategy}

Once the idea of implementing an IRM plan was accepted, several IRM strategies could have been considered for Bt crops (Andow and Hutchison, 1998). However, in the literature, the 'high-dose structured refuge' (HDR) strategy quickly emerged as a convenient tool for managing the evolution of $B t$ resistance. The 'high-dose' part of this strategy involves the use of a large enough amount or concentration of $B t$ toxin to kill all susceptible homozygous and all or most heterozygous target pests. ${ }^{5}$ Refuges are defined as habitats in which the target pest is not under selection pressure due to the toxin. These refuges correspond to all plants (crops or wild plants) that do not produce the $B t$ toxin but do provide a sustainable habitat for the development of the pest. The principle underlying the HDR strategy is that any resistant insects emerging from $B t$ crops are more likely to mate with one of the much larger number of susceptible adult pest insects emerging from the refuges than with each other, thereby decreasing the selection of $B t$ resistance alleles.

The HDR strategy was originally proposed by Georghiou and Taylor (1977) for managing the evolution of resistance to conventional insecticides. However, this strategy was not used in previous IRM plans because the doses and concentrations of insecticides cannot be controlled over time (insecticides are quickly diluted by rains and environmental factors) and space (insecticides are not

\footnotetext{
${ }^{5}$ High level of resistance to $B t$ toxin is often due to variations in a single gene. Copies of this gene that confer susceptibility to $B t$ toxin are called susceptible alleles whereas those decreasing this susceptibility are referred to as resistance alleles. All diploid individuals have two alleles of each gene. Individuals with two susceptible alleles are called susceptible homozygotes whereas those with two resistance alleles are called resistant homozygotes. Finally, individuals with one susceptible and one resistance allele are referred to as heterozygous individuals.
} 
evenly distributed over the plants and do not penetrate within plant tissues). As pointed out by Alstad and Andow (1995), the possibility of engineering genetically modified crops producing large amounts of toxin provides a unique opportunity to use the HDR strategy for delaying the appearance of widespread resistance.

The HDR strategy requires three main components if it is to be most effective (Andow and Alstad, 1998; EPA, 2001). First, survival on $B t$ corn must be a recessive trait-most heterozygous individuals carrying a resistance allele must be killed by the $B t$ toxin produced by the plant tissues. Hence, only resistant homozygotes should be able to complete their life cycle on $B t$ crops. Second, resistance alleles must be rare: the HDR strategy requires the frequency of resistance alleles in natural populations of the pest species be below $10^{-3}$ before release of the $B t$ crop. At this frequency, the proportion of resistant homozygous individuals (i.e. the proportion of individuals that will survive on transgenic $B t$ crops) is expected to be less than one in one million. Third, the HDR strategy is more effective if resistant insects selected in $B t$ crops mate randomly or preferentially with susceptible insects from the refuges.

\subsection{Collection of new empirical data and development of theoretical models}

In 1995-1996, when the planting of $B t$ corn had just begun, the parameters required for the evaluation of these three components of the HDR strategy were poorly known. Moreover, the size and location of refuges were a matter of considerable debate (EPA, 1998, 2001). As mentioned before, the EPA required registrants to conduct further research as part of the terms and conditions for $B t$ corn registration. Hence, many research programs on the ECB have been funded by registrants and performed either by their own laboratories or by academic laboratories. In addition, land grant universities and the USDA funded scientists from the US, Mexico and Canada (some of them being members of or affiliates to the research committee NC205), to carry out research on the ecology and management of this pest. This resulted in the generation of a substantial body of data on several aspects of ECB populations over a 5-year period. We summarize below its main characteristics (we cite part of the relevant literature without trying to provide an exhaustive review).

The first set of studies performed focused directly on $B t$ resistance. These studies focused on ECB baseline susceptibility to Bt toxins (Marçon et al., 1999), the initial frequency of alleles conferring $B t$ resistance in ECB populations (Bourguet et al., 2003), new methods for detecting these alleles in natural populations (reviewed in Venette et al., 2002), modeling and simulating the evolution of Bt resistance (Onstad and Guse, 1999; Davis and Onstad,
2000; Ives and Andow, 2002), the selection of Bt-resistant strains (Bolin et al., 1999), the genetics of $B t$ resistance (Huang et al., 1999a) and tests on whether $B t$ corn produced sufficient toxin to kill ECB (Walker et al., 2000).

A second set of studies performed during this time related to elements of the biology of this pest potentially useful for validating and deploying the HDR strategy. Research focused on ECB dispersal during the adult period (Hunt et al., 2001) -ECB dispersal during the larval stage had already been studied by Ross and Ostlie (1990) —, the use of non-corn alternate host refuges (Losey et al., 2001), aggregation sites (Hellmich et al., 1998), oviposition behavior (Hellmich et al., 1999) and oviposition rates (Pilcher and Rice, 2001).

These data validated two of the three components of the HDR strategy. First, the frequency of $B t$ resistance alleles in Northern US Corn Belt populations of ECB seems to be below $10^{-3}$ (Bourguet et al., 2003). Second, when refuges are close enough to $B t$ corn fields, dispersal of the moths revealed by the studies of Hunt et al. (2001) and Showers et al. (2001) may be sufficiently important to ensure random mating between susceptible (emerging from refuges) and resistant (emerging from $B t$ corn fields) individuals. The first component of the strategy (only resistant homozygous larvae can reach the adult stage while feeding on Bt corn) has yet to be tested because no ECB strain able to feed on $B t$ corn has yet been selected. It is, therefore, not yet possible to know whether or not the resistance of ECB to $B t$ corn is recessive.

New theoretical models have also been developed for predicting the evolution of $B t$ resistance in natural populations of target pests (e.g. Carrière and Tabashnik, 2001). These models generally concur in suggesting that if refuges produce a sufficiently large number of susceptible insects compared to the number of resistant insects emerging from $B t$ corn, and if these refuges are located close enough to the transgenic fields to ensure random mating, then the HDR strategy should significantly slow the evolution of $B t$ resistance, putting off the emergence of such resistance for several decades (see SAP, 1998). Several models have also addressed the economic tradeoff between the short-term losses and long-term benefits associated with refuges (Hurley et al., 1999, 2001, 2002). In these models, the optimal refuge level is obtained by maximizing the cumulative profits of $B t$ corn growers. Negative externalities of insect resistance to $B t$ crops on organic farmers and on health and the environment are indirectly taken into account, by adding constraints on the level of insecticide use and on resistance allele frequency to the maximization program.

\subsection{Towards mandatory refuge requirements}

The empirical and theoretical data described above gave a scientific basis to determine which refuge requirement to adopt. The actual plan put in place by the EPA for all $B t$ field 
corn resistant to the ECB resulted also from interactions with the different stakeholders. ${ }^{6}$ Mandatory requirements were implemented in the 2000 growing season.

The EPA stipulates that each grower planting $B t$ corn resistant to the ECB should assign $20 \%$ of their corn area to non- $B t$ field refuges in non-cotton growing areas (notably in the US Corn Belt) and 50\% in the southern states in which most US cotton is grown. The higher proportion of refuges required in these states is justified because corn is the major non-cotton host plant for the larvae of Helicoverpa zea moths (Gould et al., 2002). Transgenic $B t$ cotton produces a similar toxin to $B t$ corn resistant to the ECB. Hence, to preserve a sufficient number of susceptible $H$. zea moths, the EPA decided to increase the amount of non- $B t$ corn to $50 \%$ in geographical areas in which large amounts of $B t$ cotton are grown. In both cotton-growing and non cotton-growing areas, spraying of the non- $B t$ corn field refuge with chemical insecticides is allowed. Finally, based on the data collected concerning ECB biology, the ideal placement of the refuges has been determined. Current requirements specify that refuges must be within 0.5 miles $(\sim 800 \mathrm{~m})$ of $B t$ corn fields, and preferably within 0.25 miles $(\sim 400 \mathrm{~m})$. If refuges are planted within fields, the strips must be at least four rows wide.

\section{Compliance issues}

\subsection{Costs of compliance with refuge mandates for growers}

Growers face some costs if they comply with refuge mandates. The highest costs come from potential ECB damages in refuges. Average percentage yield losses in infested, untreated fields range from approximately 0 to $10 \%$, but can be as high as $20-25 \%$ for some fields in some years (ILSI, 1999). ${ }^{7}$ If we assume a typical yield of 9 tonnes/ ha, a price for corn of $\$ 80 /$ tonne, a $\$ 20 /$ ha technology cost associated with the use of $B t$ corn and isoline $B t$ and non- $B t$ hybrids, then the profit loss per hectare of untreated refuge is $\$ 16$ for a 5\% yield loss and $\$ 52$ for a $10 \%$ yield loss. Non- $B t$ insecticides may be used in the refuge (unless it is planted in strips within the $B t$ corn field). However, this option is not widely used because it is often not economically sound (Hyde et al., 1999). In addition, after using Bt corn, many growers are now more aware of the damage caused by ECB in the past (SAP, 1998). This increased awareness of ECB damage may discourage farmers from planting refuges.

Refuges also generate other costs, in addition to ECB damage. Farmers have to buy $B t$ and non- $B t$ seed instead of just $B t$ seed, to keep records for both seed types, and to plant

\footnotetext{
${ }^{6}$ The refuge requirement was a consensual decision between the different positions of the stakeholders; some of them wanted a higher proportion of refuges whereas others argued for a lower proportion.

${ }^{7}$ This cost may decrease over time if the increased adoption of $B t$ corn leads to a significant reduction of ECB populations.
}

$B t$ and non- $B t$ seeds separately. These operations result in time loss and inconvenience, and possibly also in yield losses due to delayed planting. During the growing season, operations on $B t$ and refuge corn varieties are similar (except for ECB control), as long as the varieties used are similar, differing essentially only in terms of the presence or absence of the transgene. However, if seed companies supply only a small range of conventional varieties, some farmers may end up using inadequately matched varieties in the refuge and $B t$ fields. There is little concern about this issue at the moment, because conventional seeds have a higher market share than $B t$ seeds, even in the states in which the most $B t$ corn is grown.

Full compliance is unlikely without regulation, because of two market failures. First, ECB susceptibility to $B t$ toxins is a resource common to all $B t$ growers. Farmers may therefore be reluctant to face, individually, the short-term costs associated with compliance with refuge requirements. Second, regulators are in a difficult position as they cannot check perfectly and without cost that farmers actually implement refuges, because $B t$ fields and refuge fields are identical in appearance. Imperfect monitoring of compliance provides farmers with an incentive not to implement costly IRM strategies, as their failure to comply is unlikely to be detected. We will now investigate the way in which this compliance issue has been taken into account by policymakers.

\subsection{Enhancement of compliance}

The new registration of $B t$ crops in 2001 provided specific requirements and guidelines concerning the various actions that registrants must take to enhance and to measure compliance. The way in which these general guidelines are to be effectively implemented is designed in an on-going IRM compliance assurance program (EPA, 2001). The EPA and a coalition of $B t$ corn registrants, the Agricultural Biotechnology Stewardship Technical Committee (ABSTC), agreed upon an IRM compliance assurance program in 2002. The details of this program are presented below.

To enhance compliance, registrants must continue grower education programs, which were the only actions taken to increase compliance before 2002. They must also make $B t$ corn growers sign an agreement that contractually binds them to comply with the refuge requirements, to create an enforceable obligation on these growers. Registrants will investigate tip-offs and complaints regarding alleged instances of non-compliance, to make it possible to identify and to punish growers who do not comply. They will also provide specific training for representatives who routinely make on-farm calls, to enable these representatives to identify non-compliant growers. The identification methods to be used have not been finalized, but invoice monitoring and a verbal or written questionnaire have been proposed as possible methods. Identified non-compliant 
growers will receive a warning letter and additional IRM education material, and will have to sign a contract before planting and agree to a visit during the growing season. The program also states that an identified non-compliant grower will be denied sales of $B t$ corn for at least 1 year if, during two successive years, he plants less than $15 \%$ refuge $(40 \%$ in the South), or if fewer than two thirds of his $B t$ fields are planted within half a mile of a refuge. Similarly, the program states that seed dealers identified as not fulfilling their obligations to educate and inform growers of their refuge obligations will not be allowed to sell $B t$ corn for at least 1 year (NCGA, 2002; Matten, 2002).

These incentives may be insufficient to ensure a very high level of compliance. On-farm visits may be effective at detecting non-compliant growers if farmers do not misrepresent their actions in a face-to-face interview, or if these visits actually include invoice monitoring. However, some cheating is still possible with these visits, as long as they do not include organized field visits and tissue sampling. Moreover, the number of farms to be visited is unclear. It is also unclear how the denial of sales of $B t$ corn to noncompliant growers will be enforced (Benbrook, 2001). Enforcement will require coordination between registrants, because a grower who is not allowed to buy seed from a given registrant may turn to another registrant.

Alternative methods for enhancing compliance have been discussed. The option most in line with typical enforcement policies for environmental regulations would be to set up a system of farm inspections, with fines for noncompliant growers. This option has not been retained, probably because it is politically unattractive. Registrants are unwilling to fine farmers for non-compliance with refuge requirements. Even if regulatory arrangements made it legal for the EPA to fine farmers directly, the EPA would have to give at least one warning and could demand only small fines (Taylor and Tick, 2003).

Other alternatives have been discussed, such as requiring growers to buy adequate proportions of $B t$ and non- $B t$ seeds, requiring growers to pay a deposit when purchasing $B t$ corn and refunding this deposit on evidence of purchase of non$B t$ seeds, or selling non- $B t$ seeds at a reduced price to buyers of $B t$ seeds. These methods would necessitate the monitoring of actual implementation by seed dealers. In addition, farmers might plant non- $B t$ seeds far away from their $B t$ fields, where they expect small ECB infestations (for discussion of these methods see Hurley in EPA and USDA, 1999a; EPA, 2001 and SAP, 2001; Mitchell et al., 2002). The possibility of voluntary refuge insurance, paying indemnities for ECB yield losses due to refuges, has also been discussed. In the event of ECB damage, an inspector would visit the refuge to determine the indemnity to be paid to the grower, based on observation of ECB stalk tunneling. This visit would also provide an opportunity to check compliance with refuge requirements. However, according to Mitchell et al. (2000), the private provision of such refuge insurance is unlikely, because its economic returns are too low. Indeed, although insurance companies explored this option in 1999, none entered the market for refuge insurance. Mitchell et al. (2000) also find that refuge insurance is unlikely to increase compliance significantly, because its benefit in terms of decreases in the variability of expected profits is small compared to the benefit associated with the higher yields of $B t$ corn.

\subsection{Measurement of compliance}

In 2000, the EPA required registrants to conduct surveys of grower compliance. The new registration of $B t$ crops in 2001 specified that IRM compliance among growers would continue to be evaluated by an independent third-party annual survey. Results of the third-party annual surveys required of registrants by the EPA are available for the years 2000, 2001 and 2002 (ABSTC, 2001, 2002a, 2002b). These surveys involve the use of telephone questionnaires to interview $B t$ corn growers in areas with significant amounts of $B t$ corn. They were conducted and analyzed by an independent marketing research firm commissioned by the ABSTC. Each year, 500-550 growers were surveyed, which is a reasonable sample size. ${ }^{8}$ The three surveys indicate that the proportion of respondents who had reportedly planted at least $20 \%$ refuge was between 86 and $87 \%$, and that the proportion of respondents who had reportedly followed placement requirements for refuges was between 82 and $89 \%$. The presentation of the results may be criticized on several grounds. First, figures about compliance with the size requirement may be misleading because this requirement differs between regions. For example, in 2002, $86 \%$ of respondents overall planted at least $20 \%$ refuge, but this figure includes respondents in the South where the required refuge is $50 \%$. Second, since farmers have to follow size and placement refuge requirements, the results should indicate the level of compliance with both requirements. The 2000 growing season survey indicates that $71 \%$ reportedly complied with both requirements, but the information is not provided for 2001 and 2002. Third, the survey only includes farms with more than 200 acres of corn. USDA NASS data for the 2002 growing season indicates that $34 \%$ of farms with less than 200 acres of corn did not comply with the size refuge requirement in ten major states having a $20 \%$ refuge requirement (Jaffe, 2003; USDA NASS, 2003). ${ }^{9}$ This tends to indicate that ABSTC compliance results would be lower if the survey included small corn growers. Fourth, the proportion of respondents is provided only in 2001 (85\%),

\footnotetext{
${ }^{8}$ If the response rate is about $85 \%$, so that the effective sample size is around 470 , it can be calculated that the $95 \%$ confidence interval of the results is around $(-1+4 \%$ if the sample is random. This confidence interval is calculated as $1.96 \sqrt{[0.7(1-0.7) / 470]}$, based on the Gaussian approximation of a Binomial distribution.

${ }^{9}$ The NASS survey indicates that $13 \%$ of farms with more than 200 acres of corn did not comply with the size requirement. This figure is coherent with the result from the ABSTC survey.
} 
and one may expect a lower compliance level among nonrespondents.

Although it is unfortunate that these results are not presented more transparently, they nonetheless give an indication of the level of compliance with refuge mandates. However, as generally agreed by the members of the 2001 SAP, grower surveys, although useful, are not a reliable tool for assessing grower compliance with refuge requirement, because non-complying growers may misrepresent their actions (SAP, 2001). ${ }^{10}$ Other methods exist for the measurement of compliance, but are likely to be more costly. Benbrook (2001) suggested that seed receipts could be reviewed to check that farmers bought the correct proportions of $B t$ and non- $B t$ corn seeds, and that at least some visits could include field visits and sampling of plant tissue in refuges. A quick-strip test could be used to confirm that the variety planted is actually non- $B t$.

\section{Resistance monitoring}

Whereas compliance was not immediately taken up as a key issue for the HDR strategy, a resistance monitoring program appeared to be an obvious and necessary component of this IRM plan. The aim of this monitoring is to detect the emergence of $B t$ resistance, evaluating the effectiveness of current HDR strategies and/or the lack of growers' compliance.

The following techniques have been considered as possible approaches to monitoring: growers' reports of unexpected damage, systematic in-field screening of $B t$ corn, lethal dose bioassays, diagnostic doses, $\mathrm{F}_{2}$ screen, feeding disruption assays, feral assays. We will not describe each of these techniques in detail here. Readers interested in these details are encouraged to read the papers of Andow and Hutchison (1998) and Venette et al. (2002).

\subsection{Methods currently implemented}

The two techniques chosen by the EPA for monitoring $B t$ resistance are dose-response bioassays and diagnostic dose assays.

Dose-response bioassays consist of detecting shifts in $\mathrm{EC}_{50}$ values (the amount of $\mathrm{Bt}$ toxin responsible for $50 \%$ growth inhibition) and/or shifts in $\mathrm{LC}_{50}$ values (the concentration of $B t$ toxin necessary to kill $50 \%$ of the larvae). The resistance ratio is the ratio of the $\mathrm{EC}_{50}$ or $\mathrm{LC}_{50}$ values in two ECB populations: a population sampled from corn fields in Bt corn-growing areas and a laboratory strain. An increase in the resistance ratio indicates a decrease in the susceptibility of ECB populations to the $B t$ toxin produced

\footnotetext{
${ }^{10}$ This Panel serves as the primary scientific peer review mechanism of the Office of Pesticide Programs in EPA and is structured to provide expert assessment of pesticide and pesticide-related matters facing the Agency (SAP (Scientific Advisory Panel), 2001).
}

by $B t$ corn. The sensitivity of this method is low. Indeed, a significant increase in the resistance ratio is unlikely to be detected unless the frequency of resistant individuals is fairly high (at least 20\%) (Roush and Miller, 1986). Thus, if resistance is recessive, a change can only be detected in dose-response bioassays once the frequency of the resistance allele exceeds $40 \%$. Therefore, regardless of sample size, we believe that this method is more appropriate for the confirmation of high levels of resistance rather than for monitoring the early emergence of ECB resistance to $B t$ corn.

The diagnostic dose technique is based on the use of a single dose of $B t$ toxin, corresponding to the $\mathrm{LC}_{99}$ value for susceptible strains (i.e. the dose that kills $99 \%$ of susceptible larvae). At this dose, only resistant individuals are expected to survive. This technique involves a single-dose assay, making it possible to screen larger numbers of individuals, resulting in higher sensitivity and lower cost than for the dose-response assay. However, this technique is greatly limited by sample size. Roush and Miller (1986) calculated that when resistant insects account for $1 \%$ of the population, the diagnostic doses assay must be performed on a minimum of 300 individuals in order to detect them with a $95 \%$ probability of detection. A larger sample is required if heterozygous individuals can be killed by the dose applied. As noted by Venette et al. (2002) a diagnostic dose test is, therefore, more likely to detect dominant resistance alleles and would be inefficient at detecting recessive alleles unless their frequencies exceed $10 \%$. Thus, a diagnostic assay is unlikely to detect resistance early, which is essential for a timely, adaptive response to the evolution of $B t$ resistance in ECB populations.

Recessivity is one of the assumptions underlying implementation of the HDR strategy (Alstad and Andow, 1995). Surprisingly, the methods chosen for the monitoring are based on the assumption that $B t$ resistance is dominant. Checking that the frequency of resistance alleles is $<1 \%$ would require the sampling and testing of thousands of individuals. In 1999, a member of the SAP panel indicated that a target of 500-1000 insects should be collected per location (EPA, 2001 page IID52). The decision that has been taken is that 200 larvae, 200 adults, 100 mated females or 100 egg masses should be sampled from 16 populations (four of which should be collected from four states in which large amounts of $B t$ corn are grown). The smallest valid collection, when collection conditions are not favorable, would be 50 larvae, 50 adults, 25 mated females or 25 egg masses.

\subsection{Alternative methods}

Two methods with potentially higher sensitivity for detecting resistance alleles have not been chosen for the monitoring: the $\mathrm{F}_{2}$ screen proposed by Andow and Alstad (1998) and the in-field screen suggested by Venette et al. (2000). 
The $F_{2}$ screen method is conducted by sampling mated adult females from natural populations, establishing isofemale lines in laboratory conditions and screening the $\mathrm{F}_{2}$ progeny of each line for $B t$ susceptibility. This technique increases the efficiency of measuring rare recessive alleles in natural populations, because $250 \mathrm{~F}_{2}$ isofemale lines provide results equivalent to the screening of $10^{6}$ insects by the diagnostic dose assay (Andow and Alstad, 1998). Indeed, if none of the progeny of $\sim 750$ isofemale lines survive to the $F_{2}$ screen, it is possible to conclude with $95 \%$ confidence that the frequency of $B t$ resistance alleles is $<10^{-3}$. However, Zhao et al. (2001) showed that the $\mathrm{F}_{2}$ screen may underestimate the frequency of resistance alleles with false negatives (isofemale lines classified as negative whereas they actually contain a $B t$ resistance allele), or fail to detect true resistance alleles. Zhao et al. (2001) and Hawthorne et al. (quoted in EPA, 2001) concluded that further validation of this method should be conducted before the $F_{2}$ screen can be used routinely for the detection of rare $B t$ resistance alleles in field populations. It should be pointed out that having an appropriate screening method to distinguish resistant and susceptible phenotypes is not a problem of the $F_{2}$ screen only. The same problem is shared by other monitoring methods, including the discriminating dose assay. It should also be pointed out that an $F_{2}$ screen performed by Génissel et al. (2003) on Chrysomela tremulae, a beetle pest, detected alleles conferring resistance to $B t$ poplar.

The in-field screen concept involves using the $B t$ corn itself as an in-field discriminatory dose for wild ECB populations (Venette et al., 2000). The density of ECB collected in the $B t$ corn is compared with the density in a non- $B t$ corn plot located close by. This comparison provides an indirect estimate of the frequency of resistant insects. The sample size required for the in-field screen depends upon the density of the ECB population exposed to the $B t$ corn and the frequency of resistant individuals in the ECB population. The final sensitivity of this method depends on these two factors and the final sample size taken. Venette et al. (2002) calculated that, with an assumed resistance frequency of $10^{-3}$ and an ECB density on non $B t$ corn of two larvae per ear, $1000 \mathrm{Bt}$ plants must be examined to achieve $95 \%$ sensitivity.

Hawthorne et al. (quoted in EPA, 2001) pointed out potential problems that must be addressed prior to the adoption of the in-field screen in the monitoring protocol, notably the risk that a high number of false positives would reduce the efficiency and accuracy of resistance allele frequency measurement. Hawthorne et al. (quoted in EPA, 2001) also noted that the efforts required during harvest to complete an in-field screen limit the practicality of this method.

These two methods, which would be really effective at detecting low frequencies of alleles conferring recessive resistance-the $F_{2}$ screen and the in-field screen-have not yet been incorporated into the monitoring protocol. These techniques may lack specificity and may be more expensive (but see the cost analysis of the $\mathrm{F}_{2}$ screen performed by Andow and Ives, 2002) and more time consuming than current methods. However, as pointed out by Venette et al. (2002), for the detection of rare individuals, gains in sensitivity are often more valuable than gains in specificity.

\section{Conclusion}

The IRM plan implemented in the US for management of the evolution of ECB resistance to $B t$ corn has been the object of an impressive amount of scientific research, debate and exchanges between stakeholders. The IRM plan currently in place, 8 years after the first $B t$ corn varieties were approved for release, forms a coherent whole, including mandatory refuges, actions to enhance growers' compliance, a program to monitor the evolution of resistance and a remedial plan if such an evolution is detected. ${ }^{11}$ However, our analysis suggests that two components of this IRM plan are not entirely satisfactory: growers' compliance and monitoring of the evolution of resistance. Moreover, these two components are delegated to registrants, who are likely to have less incentive than the social optimum for the success of IRM.

Despite these flaws, there is still no evidence of $B t$ resistance in natural populations of the ECB, 8 years after the first planting of $B t$ corn varieties (Tabashnik et al., 2003). In addition, laboratory selection for $B t$ resistance has failed to detect ECB larvae that could actively feed on $B t$ corn tissues. The frequency of $B t$ resistance alleles in ECB populations may have been very low prior to the introduction of $B t$ corn varieties. Thus, even though selection may be currently ongoing, resistance alleles may still be at sufficiently low frequencies to remain undetected. Alternatively, the absence of $B t$ resistance in ECB field populations may truly be due to the efficacy of the IRM strategy. The efficacy of this strategy may have been increased by the low rate of adoption of $B t$ corn. Indeed, although the acreage of $B t$ corn increased rapidly from $1 \%$ (1996) to $21 \%$ (1998) of the total corn acreage, it did not further increase between 1998 and 2002. In other words, no less than $75 \%$ of corn fields have been planted with non- $B t$ varieties since the early days of $B t$ corn, providing a huge refuge for susceptible ECB larvae.

These 'unstructured' refuges were not part of the IRM plan. Indeed, the size and location of the refuges of the HDR strategy were defined under the assumption that all farmers would plant $B t$ corn. The unplanned maintenance of a high level of conventional corn has certainly increased the size of refuges. However, the extent to which these extra refuges have helped to preserve ECB susceptibility to the $B t$ toxins produced by $B t$ corn is unknown. $B t$ corn was not evenly

\footnotetext{
${ }^{11}$ This plan is described in (EPA, 2001).
} 
planted within the Corn Belt. In some counties, conventional corn fields do not provide the proportion of refuges required by the HDR strategy (20\%). Moreover, they are not always close enough (i.e. $<800 \mathrm{~m}$ ) to $B t$ corn fields. In these counties, mandatory refuges are definitely a keystone component of efforts to delay the evolution of $B t$ resistance. However, 'unstructured' refuges may provide a margin of security for buffering the consequence of $B t$ corn growers that do not follow the refuge requirements.

In conclusion, the IRM plan implemented by the EPA results from a consensual position, taking into account the conflicting interests of stakeholders, and does not have a clearly defined goal. Our analysis suggests that some alternatives to the IRM plan currently in place could improve growers' compliance and monitoring of the evolution of resistance in particular. The adaptive management response proposed by Andow and Ives (2002) to hedge against failures in the scientific assumptions underlying the 'high-dose structured refuge' strategy could be an another possibility to improve the durability of $B t$ corn. However, additional research and cost-benefit analysis are required to assess the extent to which these alternatives are warranted. Clarification of the objectives of the IRM plan would also be required to assess in detail the desirability of policies on compliance and monitoring.

\section{Acknowledgements}

We thank all those who kindly agreed to be interviewed for the purpose of the study, and all those who provided us with helpful comments and suggestions on a previous version of the paper. These people were from the EPA (Sharlene Matten and Alan Reynolds), Monsanto, Pioneer, Iowa State University, University of Illinois, University of Texas, Union of Concerned Scientists. We also thank three anonymous referees. This work was funded by the French Ministry of Research, MENRT A.O. 'Impact des OGM'. The essay represents only the views of the authors.

\section{References}

ABSTC (Agricultural Biotechnology Stewardship Technical Committee), 2001. Bt corn insect resistance management survey: 2000, growing season.

ABSTC (Agricultural Biotechnology Stewardship Technical Committee), 2002a. Bt corn insect resistance management survey: 2001 growing season.

ABSTC (Agricultural Biotechnology Stewardship Technical Committee), 2002b. Bt corn insect resistance management survey: 2002 growing season.

Alstad, D.N., Andow, D.A., 1995. Managing the evolution of insect resistance to transgenic plants. Science 268, 1894-1896.

Andow, D.A., Alstad, D.N., 1998. F2 screen for rare resistance alleles. Journal of Economic Entomology 91, 572-578.
Andow, D.A., Hutchison, W.D., 1998. Bt corn resistance management. In: Mellon, M., Rissler, J. (Eds.), Now or Never: Serious New Plans to Save a Natural Pest Control. Union Concerned Scientists, Two Brattle Square, Cambridge, MA.

Andow, D.A., Ives, A.R., 2002. Monitoring and adaptive resistance management. Ecological Applications 12, 1378-1390.

Benbrook, C.M., 2001. New science shows that current $B t$-corn and cotton IRM plans will not significantly delay resistance to $B t$-based pest management technologies 2001. Comments Submitted on Behalf of Environmental Defense and the The Union of Concerned Scientists, Appendix 2. $26 \mathrm{p}$.

Bolin, P.C., Hutchison, W.D., Andow, D.A., 1999. Long-term selection for resistance to Bacillus thuringiensis CryIA(c) endotoxin in a Minnesota population of European corn borer (Lepidoptera: Crambidae). Journal of Economic Entomology 92, 1021-1030.

Bourguet, D., Chaufaux, J., Séguin, M., Buisson, C., Hinton, J.L., Stodola, T.J., Porter, P., Cronholm, G., Buschman, L.L., Andow, D.A., 2003. Frequency of alleles conferring resistance to $B t$ maize in French and US corn belt populations of the European corn borer, Ostrinia nubilalis. Theoretical and Applied Genetics 106, 12251233.

Carrière, Y., Tabashnik, B., 2001. Reversing insect adaptation to transgenic insecticidal plants. Proceedings of the Royal Society of London B 269, $1475-1480$.

Davis, P.M., Onstad, D.W., 2000. Seed mixtures as a resistance management strategy for European corn borers (Lepidoptera: Crambidae) infesting transgenic corn expressing Cry $1 \mathrm{Ab}$ protein. Journal of Economic Entomology 93, 937-948.

EPA (Environmental Protection Agency), 1998. The Environmental Protection Agency's White Paper on Bt Plant-Pesticide Resistance Management. Washington, DC 1998.

EPA (Environmental Protection Agency), 2001. Biopesticides Registration Action Document: Bacillus thuringiensis Plant-Incorporated Protectants (10/16/01) 2001.

EPA and USDA (Environmental Protection Agency and United States Department of Agriculture), 1999a. Proceedings of the EPA/USDA workshop on $B t$ crop resistance management, Rosemont, IL, June 18.

EPA and USDA (Environmental Protection Agency and United States Department of Agriculture), 1999b. Proceedings of the EPA/USDA Workshop on Bt crop resistance management in cotton, Memphis, TN, August 26.

Federal Register, 2001. 66:139, 37772-37817. US Government Printing Office.

Génissel, A., Augustin, S., Courtin, C., Pilate, G., Lorme, P., Bourguet, D., 2003. Initial frequency of alleles conferring resistance to $B t$ poplar in a field population of Chrysomela tremulae. Proceedings of the Royal Society of London B 270, 791-797.

Georghiou, G.P., Taylor, C.E., 1977. Operational influences in the evolution of insecticide resistance. Journal of Economic Entomology $70,653-658$

Glaser, J.A., Matten, S.R., 2003. Sustainability of insect resistance management strategies for transgenic Bt corn. Biotechnology Advances $22,45-69$.

Gould, F., 1998. Sustainability of transgenic insecticidal cultivars: integrating pest genetics and ecology. Annual Review of Entomology 43, 701-726.

Gould, F., Blair, N., Reid, M., Rennie, T.L., Lopez, J., Micinski, S., 2002. Bacillus thuringiensis-toxin resistance management: stable isotope assessment of alternate host use by Helicoverpa zea. Proceedings of the National Academy of Science of the USA 99, 16581-16586.

Green, M.B., LeBaron, H.M., Moberg, W.K. (Eds.), 1990. Managing Resistance to Agrochemicals: from Fundamental Research to Practical Strategies. American Chemical Society, Washington, DC.

Hellmich, R.L., Pingel, R.L., Hansen, W.R., 1998. Influencing European corn borer (Lepidoptera: Crambidae) aggregation sites in small grain crops. Environmental Entomology 27, 253-259. 
Hellmich, R.L., Higgins, L.S., Witkowski, J.F., Campbell, J.E., Lewis, L.C., 1999. Oviposition by European corn borer (Lepidoptera: Crambidae) in response to various transgenic corn events. Journal of Economic Entomology 92, 1014-1020.

Huang, F., Buschman, L.L., Higgins, R.A., McGaughey, W.H., 1999a. Inheritance of resistance to Bacillus thuringiensis toxin (Dipel ES) in the European Corn Borer. Science 284, 965-967.

Hueth, D., Regev, U., 1974. Optimal agricultural pest management with increasing pest resistance. American Journal of Agricultural Economics $56,543-553$.

Hunt, T.E., Higley, L.G., Witkowski, J.F., Young, L.J., Hellmich, R.L., 2001. Dispersal of adult European corn borer (Lepidoptera: Crambidae) within and proximal to irrigated and nonirrigated corn. Journal of Economic Entomology 94, 1369-1377.

Hurley, T.M., Secchi, S., Babcock, B.A., Hellmich, R.L., 1999. Managing the risk of European Corn Borer resistance to transgenic corn: an assessment of refuge recommendations. Center for Agricultural and Rural Development Staff Report 99 SR88. Iowa State University, Ames, IA.

Hurley, T.M., Babcock, B., Hellmich, R.L., 2001. Bt crops and insect resistance: an economic assessment of refuges. Journal of Agricultural and Resource Economics 26, 176-194.

Hurley, T.M., Secchi, S., Babcock, B.A., Hellmich, R.L., 2002. Managing the risk of European Corn Borer resistance to $B t$ corn. Environmental and Resource Economics 22, 537-558.

Hyde, J., Martin, M.A., Preckel, P.V., Edwards, C.R., 1999. The economics of $B t$ corn: valuing protection from the European Corn Borer. Review of Agricultural Economics 21, 442-454.

International Life Sciences Institute, 1999. An evaluation of insect resistance management in $B t$ field corn: a science-based framework for risk assessment and risk management. Report of an expert panel. November 23, 1998. $85 \mathrm{p}$.

Ives, A.R., Andow, D.A., 2002. Evolution of resistance to Bt crops: directional selection in structured environments. Ecology Letters 5, $792-801$.

Jaffe, G., 2003. Planting Trouble Update. Center for Science in the Public Interest, Washington, DC.

Losey, J.E., Calvin, D.D., Carter, M.E., Mason, C.E., 2001. Evaluation of non-corn host plants as a refuge in a resistance management program for European corn borer (Lepidoptera: Crambidae) on Bt-corn. Environmental Entomology 30, 728-735.

Marçon, P.C.R.G., Young, L.J., Steffey, K.L., Siegfried, B.D., 1999. Baseline susceptibility of European corn borer (Lepidoptera: Crambidae) to Bacillus thuringiensis toxins. Journal of Economic Entomology 92, 279-285.

Matten, S.R., 2002. Personal communication, December 9.

Mellon, M., Rissler, J., 1998. Now or never: Serious New Plans to Save a Natural Pest Control. Union of Concerned Scientists.

Mitchell, P.D., Hurley, T.M., Hellmich, R.L.,2000. Economic Evaluation of $\mathrm{Bt}$ Corn Refuge Insurance. CARD Working Paper 00-WP 243. Ames, IA p. 26.

Mitchell, P.D., Hurley, T.M., Babcock, B.A., Hellmich, R.L., 2002. Insuring the stewardship of $B t$ corn-a carrot versus a stick. Journal of Agricultural and Resource Economics 27, 390-405.

NCGA (National Corn Grower Association), 2002. EPA, Ag Biotech Companies Announce IRM Compliance Assurance Program. Press Release, November 15.

NRC (National Research Council), 1986. Pesticide Resistance: Strategies and Tactics for Management. Committee on Strategies for the Management of Pesticide Resistant Pest Populations. National Academy Press, Washington, DC.

NRC (National Research Council), 2000. Genetically Modified PestProtected Plants: Science and Regulation. Committee on Genetically
Modified Pest-Protected Plants, Board on Agriculture and Natural Resources. National Academy Press, Washington, DC.

Onstad, D.W., Guse, C.A., 1999. Economic analysis of transgenic maize and nontransgenic refuges for managing European corn borer (Lepidoptera: Pyralidae). Journal of Economic Entomology 92, 1256-1265.

Pilcher, C.D., Rice, M.E., 2001. Effect of planting dates and Bacillus thuringiensis corn on the population dynamics of European corn borer (Lepidoptera: Crambidae). Journal of Economic Entomology 93, 730742.

Regev, U., Shalit, H., Gutierrez, A.P., 1983. On the optimal allocation of pesticides with increasing resistances: the case of alfalfa weevil. Journal of Environmental Economics and Management 10, 86-100.

Ross, S.E., Ostlie, K.R., 1990. Dispersal and survival of early instar larvae of European corn borer (Lepidoptera: Pyralidae) in field corn. Journal of Economic Entomology 83, 831-836.

Roush, R.T., 1998. Two-toxin strategies for management of insecticidal transgenic crops: can pyramiding succeed where pesticide mixtures have not?. Philosophical Transactions of the Royal Society of London Series B-Biological Sciences 353, 1777-1786.

Roush, R.T., Miller, G.L., 1986. Considerations for design of insecticide resistance monitoring programs. Journal of Economic Entomology 79, 293-298.

SAP (Scientific Advisory Panel), 1998. Final report of the FIFRA Scientific Advisory Panel Subpanel on Bacillus thuringiensis (Bt) plant-pesticides and resistance management, February 9-10, 1998. US Environmental Protection Agency, Washington, DC.

SAP (Scientific Advisory Panel), 2001. Final report of the FIFRA Scientific Advisory Panel Subpanel on Insect Resistance Management, October 18-20, 2000, Sets of scientific issues being considered by the Environmental Protection Agency regarding Bt plant-pesticides risk and benefit assessments. US Environmental Protection Agency, Washington, DC.

Showers, W.B., Hellmich, R.L., Derrick-Robinson, M.E., Hendrix III., W.H., 2001. Aggregation and dispersal behaviour of marked and released European corn borer (Lepidoptera: Crambidae) adults. Environmental Entomology 30, 700-710.

Tabashnik, B.E., Carrière, Y., Dennehy, T.J., Morin, S., Sisterson, M.S., Roush, R.T., Shelton, A.M., Zhao, J.-Z., 2003. Insect resistance to transgenic $B t$ crops: lessons from the laboratory and field. Journal of Economic Entomology 96, 1031-1038.

Taylor, M., Feyereisen, R., 1996. Molecular biology and evolution of resistance to toxicants. Molecular Biology and Evolution 13, 719-734.

Taylor, M.R., Tick, J.S., 2003. Post-market oversight of biotech foods: is the system prepared?, Pew Initiative on Food and Biotechnology, Washington, DC 2003.

USDA NASS, 2003. Corn and biotechnology special analysis, Washington, DC 2003.

Venette, R.C., Hutchison, W.D., Andow, D.A., 2000. An in-field screen for early detection and monitoring of insect resistance to Bacillus thuringiensis in transgenic crops. Journal of Economic Entomology 93, 1055-1064.

Venette, R.C., Moon, R.D., Hutchison, W.D., 2002. Strategies and statistics of sampling for rare individuals. Annual Review of Entomology 47, 143-174.

Walker, K.A., Hellmich, R.L., Lewis, L.C., 2000. Late-instar European corn borer (Lepidoptera: Crambidae) tunneling and survival in transgenic corn hybrids. Journal of Economic Entomology 93, 12761285 .

Zhao, J.H., Li, Y.X., Collins, H.L., Shelton, A.M., 2001. Examination of the F2 screen for rare resistance alleles to Bacillus thuringiensis toxins in the diamondback moth (Lepidoptera: Plutellidae). Journal of Economic Entomology 95, 14-21. 